\title{
Corrupt Environment, Marketization Level and Growth of Five-star Hotel Industry
}

\author{
Tingting Zhou (Corresponding author) \\ Dept. of Financial Management, Beijing International Studies University \\ Zhixing Building 528, Business School, Beijing International Studies University, No.1 \\ Dingfuzhuang Nanli, Chaoyang District, 100024, China \\ Tel: 86-185-1166-3649Ｅ-mail: nkjanett@163.com
}

Jing $\mathrm{Yu}$

Zhongfa Industrial (Group) CO. LTD

Jing Yu. No 67, Road Xisihuanbei, Haidian District, China, 100195

Tel: 86-188-1174-5747Ｅ-mail: yujing19946@163.com

Junnuo Shi

Dept. of Financial Management, Beijing International Studies University

Business School, Beijing International Studies University, No.1 Dingfuzhuang Nanli, Chaoyang District, 100024, China

Tel: 86-135-5299-6569Ｅ-mail: shijunnuo@126.com

Received: October 10, 2019 Accepted: November 22, 2019 Published: November 24, 2019

doi:10.5296/ieb.v5i2.15890

URL: https://doi.org/10.5296/ieb.v5i2.15890

\begin{abstract}
Under the situation of frequent corruption behaviors of government officials and strict requests on cracking down on corruption, using the panel data of provincial five-star hotels, this paper investigates the existence and continuity of development model of "Corruption Economy" in five-star hotel industry, and detects the way for sustainable development of five-star hotel industry on the background of anti-corruption from the perspective of
\end{abstract}


marketization. The results show that degree of state corruption represented by Control of Corruption has a positive effect on the growth of five-star hotel industry. Anti-corruption policies in litigation system, the efforts of implementing these policies to combat corruption, and public's perceived corruption and anti-corruption all verify a negative impact on five-star hotel industry. Practice shows that anti-corruption breaks the false prosperity of "corruption economy" model. Only with a perfect market system as well as fair market competition order, the five-star hotel industry can realize a sustainable growth.

Keywords: Corruption, Anti-corruption, Five-star hotel, Marketization process

\section{Introduction}

In the course of the development and perfection of socialist market economy, corruption and anti-corruption have always been the focus of the society. Corruption is generally interpreted as the use of public power to seek private interests (Aidt, 2009). In the study of economics, corruption is defined as "the behavior of government officials as rational economic men who violate the rules for private gain". The origins of corruption and its impact on economic growth have been widely concerned by economists. However, there is no consistent conclusion on the mechanism of corruption on economic growth. The current research on corruption efficiency mainly includes two viewpoints: "effective perspective of corruption" and "harmful perspective of corruption".

The point of effective corruption holds that corruption has a positive effect on economic development, and anti-corruption has a negative effect on economic growth. To a certain extent, corruption helps entrepreneurs obtain the priority of public service queuing under the background of inefficient administrative control, and promotes the optimization of resource allocation. Corruption promotes economic growth when a country's administrative system or legal system is imperfect or even defective, for corruption breaks the irrationality of government administrative control. Enterprises can use bribery to promote production and operation, and its rent-seeking expenditure is less than the bribery income, which is conducive to economic growth. Using panel data from 31 provinces in China, Wang (2016) finds that anti-corruption reduces investment efficiency and inhibits economic growth. Rock and Bonnett (2004) use transnational samples to conduct empirical researches, find that corruption promotes investment and economic growth in East Asian emerging industrial economies, which also explains the coexistence of high corruption and high economic growth in some East Asian countries. By taking transnational data as the research sample and measured economic growth with per-capita real growth, Barreto(2001) finds that corruption plays a significant role in promoting economic growth. Since anti-corruption has broken the long term development model of the "corrupt economy", sustained anti-corruption has caused a great impact on the enterprises, especially for those relying on Rent-seeking and government privileges to protect their development.

The perspective of pernicious corruption argues that corruption hinders economic growth (Pulok \& Ahmed, 2017), and anti-corruption boosts economic growth. Corruption distorts the allocation of talents and resources and reduces the efficiency of public expenditure. D'agostino et al. (2016) using data samples from 106 countries, find that corruption has reduced government investment and military spending, with a negative impact on economic 
growth. Ghalwash (2014) points out that corruption has reduced government spending, reduced investment, reduced human capital and inhibited economic growth. Alm et al. (2016 argue that corruption leads to tax evasion, and corruption among tax officials is an important determinant of tax evasion. Aidt (2009) uses growth in genuine wealth per capita as a measure of economic sustainable development, finds that corruption has an inhibitory effect on sustainable economic development. Mo (2001) argues that corruption through political instability. Reducing human capital and reducing the level of private investment play a restraining role on economic growth; Mo (2001) finds that corruption exerts an inhibitory effect on economic growth through three channels: political instability, reducing human capital and lowering the level of private investment. By using the Intercountry panel data (1984-2007), Swaleheen(2001) shows that corruption has a reverse effect on economic growth.

From the macroeconomic perspective of our country, the research of economic consequence of corruption analyzes and discusses the relationship among corruption, anti-corruption and the overall economic operation. Since China is in the stage of economic and social transformation, the development of socialist market economy is not coming of age, which cause great differences in the development of different industries. Therefore, it is more instructive to study the relationship of corruption, anti-corruption with specific industries and enterprises in order to promote the coordinated development of various industries, perfect the market economic system, and enhance the overall economic strength. However, there are few literatures on this aspect.

China's anti-corruption policies have had a far greater impact on its hotel industry than any other. Accommodation and catering costs incurred by government officials on official visits are usually provided by five-star hotels. In the income constitution of five-star hotels, the visible and invisible consumer expenditure from the government occupies a large proportion. Star hotel industry in China has great potential for development, and the development of star hotels is of great significance to improve the output value of tourism. The development of five-star hotels plays an important role in the development of the whole star-rated hotel industry and the tourism economy of China. According to the statistics bulletin of the national star-rated hotels, in the fourth quarter of 2015, in the national star-rated hotels, the numbers of five-star hotels is $7 \%$, the proportion of business income is 35 . Has anti-corruption broken the "corrupt economy" mode of five-star hotels under the high-pressure situation of punishing corruption? What is the development principles of five-star hotels in China?

In view of the above questions, using the national and provincial five-star hotel industry panel data as a sample, based on the World Bank's global government governance index database of corruption control index, anti-corruption policy and effectiveness measurement index system, this paper analyze the mechanism of national corruption, regional anti-corruption on the growth of five-star hotel industry, and the effective path to the development of five-star hotel industry under the high pressure of anti-corruption from the perspective of market-oriented process. This study finds that corruption promotes the development of five-star hotel industry in China. However, under the malformed development mode of "corrupt economy", five-star hotels can not realize sustainable growth by relying on the corrupt behavior of government officials and the protection of privileges. 
China's persistent and high-pressure anti-corruption situation has broken the apparent prosperity of the "corrupt economy" and has had a negative impact on the growth of the five-star hotel industry. But perfect market-oriented operation mechanism can restrain the negative influence of anti-corruption on five-star hotel income growth.

This study contributes to the current literature in the following two aspects. First, this paper takes five-star hotels as the research object, discusses the potential impact of corruption and anti-corruption on the development of five-star hotels, and provides empirical evidence from the five-star hotel industry for the theory of corruption economy. Second, based on the harmful corruption theory, this paper proposes the development path for five-star hotels to cope with the anti-corruption environment, namely, pay attention to the innovation of service mode and the diversified needs of customers by perfecting the regional market mechanism, and thus expand the rent-seeking theory.

The rest of the paper is organized as follows. Section 2 develops hypotheses. Section 3 describes the data set and regression models. We present the results of empirical tests in Section 4, while Section 5 concludes the paper.

\section{Hypotheses}

In the hypothesis of "Rational Economic Man", government officials tend to maximize their personal interests, which drive them to possess the price difference between the planned allocation price and the market price. That is, seizing the "economic rent". According to rent-seeking theory, government officials will use privileges to interfere with the operation of the economy and create "rent" to attract operators to seek rent from them. The public power of the department is distorted when being implementation and constantly dissimilated into the personal power of the official. The privileged effect formed by it often becomes the bargaining chip of the political rent creation of the government official. Government officials, for example, have incentives to accept bribes in patents and quality certification (Paunov, 2016). Political rent creation is closely related to the degree of corruption in the country (Hessami, 2014). Political rent creation by government officials actually forms a supply of corruption. Rent-seeking theory points out that businessmen engaged in business activities try to obtain the protection of government privilege or some monopoly resources by means of legal or illegal means. In China's imperfect market economy system, the government has a greater power over resources. Limited resources lead to fierce external competition in the market. In the process of development, overtaking pressure of management can easily lead to rent-seeking behavior, which helps enterprises obtain more government support as well as interfering with the rational allocation of resources. Research by Pan and Tian (2017 point out that corruption leads to collusion between state executives and government officials for their own interests, with higher investment spending by SOEs linked to bribery after corruption has occurred. The operator's rent-seeking behavior produces the demand for corruption to a certain extent.

In essence, rent creation and rent-seeking activities cannot be separated from power and money transactions. The inefficiency and waste of resources caused by the increase in social costs and rent-seeking returns have led to negative effects of rent-seeking and rent-seeking activities, which are not conducive to long-term stable economic growth (Iqbal and Daly, 2014). The development of China's socialist market economic system is imperfect. In the 
economic development, the allocation rights, administrative management and examination and approval systems of scarce resources held by government departments give the government departments the right to choose market participants. In the process of market economy development, market entry barriers restrict some operators from entering the market, and the contradiction between resource limitation and infinite demand makes operators face fierce competition. By participating the rent-seeking activities, on the one hand, the operators can reduce the difficulty of entering the market. On the other hand, they are able to obtain the preferential use rights of limited resources. This can make enterprises occupy the dominant position in the market competition, and thus promoting the continuous development of the enterprise. With the corruption of officials, rent-seeking companies have obtained excess returns, and non-rent-seeking companies are often limited in their development. With the corruption of officials, rent-seeking companies have obtained excess returns, and non-rent-seeking companies are often restricted in their development. Official corruption has brought many benefits to bribery companies, such as lowering transaction costs and increasing company value (Cheung et al., 2012). But in countries with high levels of corruption, companies have generally low returns (Donadelli et al., 2014). Corruption has significantly inhibited national productivity (Bentzen, 2012).

The government, who has a say departments have a voice in determining the construction of five-star hotels, star rating and foreign-related business, plays an important role in the growth of five-star hotels. In the case of five-star hotels, corrupt spending by government officials is often presented in the name of official consumption, government meetings and business banquets. The direct link to government officials' corrupt spending is a five-star hotel. By establishing a relationship with government departments through rent seeking, five-star hotels can start a long-term corruption with the government, such as undertaking various government meetings, provide related entertainment, catering, accommodation and other services. This long-term cooperation will obtain a stable source of revenue. Government officials rely on the power of the department to carry out political rent-creation activities, five-star hotels through rent-seeking behavior by the support of government departments, access to limited resources, in the market competition in a favorable position. Accordingly, this paper holds that the higher the degree of corruption is the greater the space for rent-seeking by government officials and five-star hotels will be promoting the industry development of five-star hotels to a certain extent.

Hypothesis 1: The degree of corruption has a positive effect on the growth of the five-star hotel industry.

Over the years, China has maintained a high-pressure anti-corruption situation. The state has introduced a number of anti-corruption policies and regulations to regulate the behavior of government officials at the legal system level. The local supervision departments have strictly implemented relevant policies to expose officials' corrupt practices. In 2012, China has issued six anti-corruption rules, twelve in 2013 it was 12, of which 14 and 37 were related to five-star hotels. China's anti-corruption intensity continued to strengthen. According to the official data released by the Central Discipline Inspection Commission of CPC, China investigated and handled 6,158 duty crimes in the operation, management and reform of state-owned enterprises in 2014. Since Party Central Committee's eight-point decision had 
been promulgated, local governments stepped up anti-corruption construction and curbed extravagance, which gave rise to the reduction of direct official consumption, government meetings, and the consumer activities such as business banquet officials have directly affected the income growth of five-star hotels. According to the data released by the National Star Hotel Statistics Bulletin, the average house price of five-star hotels in China was 710.20 yuan/night in 2012, and the room occupancy rate was 59.91\%. By 2014, the average house price of five-star hotels nationwide fell to 678.73 yuan per night, the room occupancy rate is reduced to $55 \%$.

According to the speech of the Chairman of the National People's Congress, Mr. Duan Qiang (Beijing BTG Group) at the 2015 Beijing National Committee Plenary Session of the National People's Congress, about $70 \%$ of the five-star hotel income composition comes from government-related consumption, among which the proportion of direct government consumption is about $10 \%$ to $15 \%$, which is very small. The rest are related to the consumption of government departments or officials, including government departments' banquets, entertainment, and officials' public activities, public funds, food and drink. The decline in the business of five-star hotels under the influence of high-pressure anti-corrosion mainly comes from government-related corruption spending. Therefore, the strong advocate of the anti-corruption policy has significantly reduced the industry development speed of five-star hotels in China.

In the short-term, anti-corruption measures such as cracking down on power rent-seeking, prohibiting public funds from catering or gifts, have broken the false prosperity of the "corruption economy" and the economic growth has slowed down. Despite anti-corruption has weakened China's economic development, in the long-run perspective, anti-corruption is conducive to creating a clean and honest social atmosphere, providing a fair and honest environment for the long-term healthy development of China's economy. On the other hand, it will help to crack down on rent-seeking behavior and maintain the government's rational intervention in the economy, which can propel the process of marketization to improve China's socialist market economic system. Anti-corruption, cracking down on power rent-seeking, and purifying the market environment are actually more conducive to the sound development of the economy. It will be more conducive to the sustained and healthy development of the Chinese economy by combating corruption, removing barriers to market operating mechanisms, and giving full play to the decisive role of market allocation of resources.

Today, as anti-corruption and honesty have a far-reaching significance and steadily advance, we need to make a solution of how to achieve the benign development of five-star hotels. In areas with high levels of marketization, the role of market mechanisms in resource allocation can be fully utilized. On the one hand, the marketization process has a promoting effect on economic development. A good market development mechanism is conducive to guiding five-star hotels to participate in market competition through formal channels, reducing their dependence on government departments, and thus reducing the effect of anti-corruption on the growth of the five-star hotel industry. On the other hand, anti-corruption seeks to crack down on corrupt officials and curb the unhealthy trend of the government. In the process of economic development, the market mechanism is well developed. Government officials use 
privileged intervention in the economic operation space is small, five-star hotels receive less income based on rent-seeking behavior and government privilege protection. The negative impact of anti-corruption intensity on the revenue of five-star hotels is weak. We therefore make the following hypothesis:

Hypothesis 2: The degree of anti-corruption has a negative impact on the growth of the five-star hotel industry. And the process of marketization has restrained the decreasing effect of anti-corruption on the growth of five-star hotel industry.

\section{Sample and Research Design}

\subsection{Data Sources}

In this paper, the relationship between corruption and the growth of five-star hotel industry is studied by using the data of national level from 2000 to 2014, and the influence mechanism of anti-corruption on the growth of five-star hotel industry is discussed by using provincial level data. Data for Five-star hotel revenue is obtained from China Tourism Statistics Yearbook copy. Data for National corruption data are obtained the World Bank global government governance indicators database. The anti-corruption rules were collected from the latest anti-corruption laws and regulations of 2014 and the compilation of the Party style and Clean Government Construction and Anti-Corruption laws since the 18th National Congress of the CPC. The annual number of corruption cases, the number of cadres at or above the county level involved in corruption investigation and punishment are hand collected from the work reports of the procuratorates of the provinces in the "China Procuratorial Yearbook". The original data of inbound tourism index come from the Yearbook of China Tourism Statistics. The original data of the other variables were derived from the Statistical Yearbook of China.

\subsection{The Degree of Corruption in the Country Level and the Income of Five-Star Hotels}

The accurate measurement of the degree of corruption is an important constraint to the reliability of the conclusions of this paper. Indicators such as the number of corruption cases in the region, the number of people involved in corruption, and the number of cadres at or above the county level in anti-corruption investigations are not accurate variables for measuring the extent of regional corruption. From the perspective of time dimension, the corruption incidents investigated in the current year did not all occur in the current year, and the measurement of the degree of corruption in the region was not accurate. In terms of the quantitative, supervision departments can only deal with corrupt behaviors that reach the level of crime, but cannot deal with corrupt behaviors that actually occur but do not constitute crimes. To a certain extent, the actual level of corruption in each region is underestimate. Based on the above analysis, it is difficult to obtain accurate measures of regional corruption degree. This paper selects national level data to measure the degree of national corruption. Due to the limitation of sample size, regression analysis is not possible. This paper analyze the correlation between the degree of corruption in the country level and the income of five-star hotels. The degree of corruption at the provincial level is not considered.

The growth of the five-star hotel industry is respectively measured by the proportion of national five-star hotel revenue, room revenue, food and beverage revenue as a percentage of GDP (REVEN, SUITEN, CATERN). Regarding the degree of national corruption, 
Transparency International's CPI Corruption Index, the World Bank's CCI Corruption Control Index, and the International Country Risk Guide's ICRG Corruption Index are widely used measures. These metrics have small differences and are highly correlated. This paper uses the World Bank's Global Governance Indicators' Corruption Control Index $(C C I)$ and China's National Corruption Percentage Ranking $(R A N K)$ to measure the degree of national corruption. Based on expert assessments and questionnaires, the Corruption Control Index reflects the fact that a government's public rights are used for personal gain and is a reflection of the degree of government corruption. This index has been published since 1996, which covers 215 countries and regions around the world. RANK represents countries whose Corruption Control Index ranks lower than the proportion of China's countries, namely the proportion of countries with a higher degree of corruption than China's. This paper reverses the corruption control index and constructs a standardized corruption control index (STANDA). According to the rule of the value of the corruption control index, we employ the following formula to measure $S T A N D A$, that is $10-2 \times$ (corruption control index +2.5 . The higher the value of STANDA, the higher the level of corruption. Therefore, this paper constructs a national corruption degree measurement index system including the Corruption Control Index $(C C I)$, the China Corruption Percentage Ranking $(R A N K)$ and the Standardized Corruption Control Index (STANDA).

\subsection{The Degree of Regional Anti-Corruption and the Growth of the Five-Star Hotel Industry}

Based on the provincial-level panel data of five-star hotel industry growth from 2000 to 2014, in order to explore the relationship between the degree of anti-corruption and the growth of the five-star hotel industry at the regional level, we estimate the following regression:

$$
\begin{aligned}
\text { REVENUE }= & \alpha+\beta_{1} \text { ANTICOR }+\beta_{2} \text { MARKET }+\beta_{3} \text { ANTICOR } \times \text { MARKET }+\beta_{4} F I X+\beta_{5} \text { CONSUM }+\beta_{6} U R B+\beta_{7} C P I \\
& +\beta_{8} \text { TOUR }+\beta_{9} \text { FOUND }+\beta_{10} \text { VISITOR }+\beta_{11} \text { SERV }+\beta_{12} \text { GROUP }+\beta_{13} M A R R I+\sum Y E A R+\varepsilon
\end{aligned}
$$

Where we employ REVENUE to measure the revenue of five-star hotel, which consists of three variables: Five-star hotel total revenue as a percentage of GDP (REVE), room revenue as a share of GDP (SUITE), catering revenue as a share of GDP (CATER). ANTICOR is an anti-corruption variable that covers two metrics for a total of six indicators. The first metric is anti-corruption rules measurement. We collect the number of anti-corruption rules promulgated by the state from 2000 to 2014 and the number of articles related to anti-corruption policies involving five-star hotels to construct three indicators: Anti-Corruption Policy (ACORRU), Anti-Corruption Policy quantity (POLICY), and items of the five-star hotel related to the Anti-Corruption Policy (ITEM). ACORRU is the sum of the number of anti-corruption policies and the number of clauses concerning five-star hotels. POLICY represents the number of anti-corruption policies enacted each year. ITEM refers to the number of items of the five-star hotel related to the Anti-Corruption Policy each year. The second metric is the measure of anti-corruption effects. This paper selects the number of the corruption filings quantity $(F I L)$, the number of suspects involved in corruption filings (SUSP), and the number of cadres at the county level $(C A D)$ as the measurement of regional anti-corruption. This paper takes the logarithm of the above anti-corruption effect metrics. We calculate FIL by taking logarithm of the annual quantity of corruption filings, and get SUSP by taking logarithm of the annual quantity of suspects involved in these cases. To recognize 
$C A D$, we take logarithm of the number of cadres at or above the county level investigated and dealt with each year. This paper uses the marketization index (MARKET) compiled by Fan Gang to measure the marketization level of each region.

Five-star hotel industry growth will also be affected by social and economic factors. The regression model contains the following control variables: social fixed assets per capital $(F I X)$ is computed as the total investment in fixed assets of the whole society being divided by the total population; consumption level (CONSUM) equals the ratio of per capita consumption expenditure of urban and rural residents to revenue; urbanization level (URBAN) is a variable which takes the ratio of permanent urban population to total population; price level $(C P I)$ is figured out by Consumer price index; Moreover, in order to conditions of tourism resources of each province (TOUR), we collect by hand the number of world natural heritage, cultural heritage, natural and cultural dual heritage and national historical and cultural cities in each province each year; According to the density of railway network, grade highway and inland waterway in each province, infrastructure level (FOUND) is computed; Based on the foreign exchange income of Chinese tourism, the number of inbound foreign tourists and the number of tourists from Hong Kong, Macao and Taiwan, the principal component analysis (PCA) was used to synthesize the inbound tour index (VISITOR); Respectively, we identify the number of government officials (SERV), the number of arts performance group (GROUP) by taking logarithm of the number of government officials per year, the number of performing arts groups per year; We use the quantity that the first marriages accounts for the total number of people each year to figure up marriage rate (MARRI); YEAR represents the fiscal year dummy indicator.

\section{Empirical Results and Analysis}

\subsection{Descriptive Statistics}

Table 1 provides descriptive statistics of variables. At the national level, the average value of Total Revenue of Five-star Hotels in China, room revenue, and food and beverage revenue in GDP for the five-star hotels from 2000 to 2014 are $0.146 \%, 0.069 \%$, and $0.053 \%$, respectively. At the regional level, the average value of total revenue, room revenue, and food and beverage revenue in GDP for the five-star hotels during 2000 to 2014 are $0.125 \%$, $0.071 \%$ and $0.049 \%$, respectively. The average level of Corruption Control Index $(C C I)$, China's Corruption Percentage Ranking $(R A N K)$, and Standardized Corruption Control Index $(S T A N D A)$, which characterize national corruption, are $-0.501,38.24 \%$, and 6.000, respectively, indicating that China is a country which corrupt is more serious among worldwide.

In terms of anti-corruption policies issued by the state, the average number of anti-corruption rules $(A C O R R U)$, anti-corruption policy (POLICY) and anti-corruption policies involving five-star hotels (ITEM) are 8.400, 3.867 and 4.533 respectively. China enacted two anti-corruption policies in 2008, six in 2012, twelve in 2013. The number of the policies which involving five-star hotels is 0 in 2008, 14 in 2012, and 37 in 2013, respectively, indicating that China's anti-corruption policy is constantly strengthening. The average number of corruption cases is 1190, and the average value of the corresponding FIL is 6.804 . The average number of people involved in corruption is 1442, and the average for SUSP is 6.991. The average number of cadres at or above the county level is 94 , corresponding to an 
average of 4.295 for $C A D$. The data show that China actively introduces anti-corruption policies and regulations, and its implementation in the region level runs well.

The Marketization level (MARKET) has an average of 6.772 and a standard deviation of 2.654. The average values of consumption level (CONSUM), price level (CPI) and urbanization level $(U R B A N)$ are $0.765,1.03$ and 0.474 , respectively. The average value of fixed assets per capita $(F I X)$ is 1.497. The average level of tourism resource conditions (TOUR) and infrastructure conditions (FOUND) are 3.598 and 9.963, respectively. The average value of the inbound tourism index (VISITOR) is -0.0002 and the standard deviation is 2.299. The average number of government public officials is 415,300, corresponding to an average of 3.526 of its logarithmic SERV. The average number of performing groups is 146, corresponding to the average logarithmic GROUP of 4. 611. The average marriage rate is $1.4 \%$.

Table 1. Summary statistics

\begin{tabular}{|c|c|c|c|c|c|}
\hline Variables & Mean & Median & Std. Dev & Minimum & Maximum \\
\hline REVEN & 0.146 & 0.149 & 0.016 & 0.120 & 0.180 \\
\hline SUITEN & 0.069 & 0.070 & 0.011 & 0.050 & 0.090 \\
\hline CATERN & 0.053 & 0.052 & 0.007 & 0.040 & 0.070 \\
\hline$R E V E$ & 0.125 & 0.061 & 0.208 & 0.000 & 1.508 \\
\hline SUITE & 0.071 & 0.030 & 0.131 & 0.000 & 0.907 \\
\hline CATER & 0.049 & 0.025 & 0.073 & 0.000 & 0.480 \\
\hline$C C I$ & -0.501 & -0.543 & 0.123 & -0.650 & -0.240 \\
\hline$R A N K$ & 38.240 & 35.254 & 6.204 & 31.710 & 50.730 \\
\hline$S T A N D A$ & 6.000 & 6.085 & 0.246 & 5.480 & 6.310 \\
\hline$A C O R R U$ & 8.400 & 3.000 & 12.250 & 0.000 & 49.000 \\
\hline POLICY & 3.867 & 3.000 & 3.348 & 0.000 & 12.000 \\
\hline ITEM & 4.533 & 0.000 & 9.531 & 0.000 & 37.000 \\
\hline$F I L$ & 6.804 & 7.066 & 0.958 & 3.370 & 10.630 \\
\hline SUSP & 6.991 & 7.280 & 0.905 & 3.580 & 8.360 \\
\hline$C A D$ & 4.295 & 4.394 & 0.798 & 1.100 & 6.360 \\
\hline MARKET & 6.772 & 6.630 & 2.654 & 0.000 & 15.380 \\
\hline$F I X$ & 1.497 & 1.094 & 1.314 & 0.110 & 7.020 \\
\hline CONSUM & 0.765 & 0.745 & 0.534 & 0.590 & 12.190 \\
\hline$U R B A N$ & 0.474 & 0.450 & 0.157 & 0.190 & 0.900 \\
\hline$C P I$ & 1.030 & 1.023 & 0.136 & 0.970 & 3.920 \\
\hline TOUR & 3.598 & 3.807 & 0.763 & 2.200 & 4.780 \\
\hline FOUND & 9.963 & 9.907 & 0.857 & 7.850 & 12.290 \\
\hline VISITOR & -0.0002 & -0.670 & 2.299 & -1.220 & 16.380 \\
\hline$S E R V$ & 3.526 & 3.674 & 0.731 & 1.660 & 4.800 \\
\hline GROUP & 4.611 & 4.635 & 0.944 & 2.480 & 7.170 \\
\hline MARRI & 0.014 & 0.014 & 0.004 & 0.003 & 0.028 \\
\hline
\end{tabular}




\section{Macrothink}

4.2 The Correlation between National Corruption and the Income of Five-Star Hotels

Figure 1 to 3 show a collection of dynamic curves between national corruption and national five-star hotel revenue. As shown in the figures, during the period of 2000-2014, the Corruption Control Index $(C C I)$ and China's Corruption Percentage Ranking $(R A N K)$ show a trend of rising volatility as a whole, while the Standardized Corruption Control Index (STANDA) shows a trend of decreasing volatility. These indicates that the degree of corruption in China tends to decline overall; Total five-star hotel revenue, room revenue, and food and beverage revenue tends to decline. According to the preliminary analysis, there is a positive correlation between the degree of national corruption and the growth of five-star hotel industry in China, which verifies China's "corrupt economy" model, indicating that the degree of corruption promotes the development of China's five-star hotel industry.

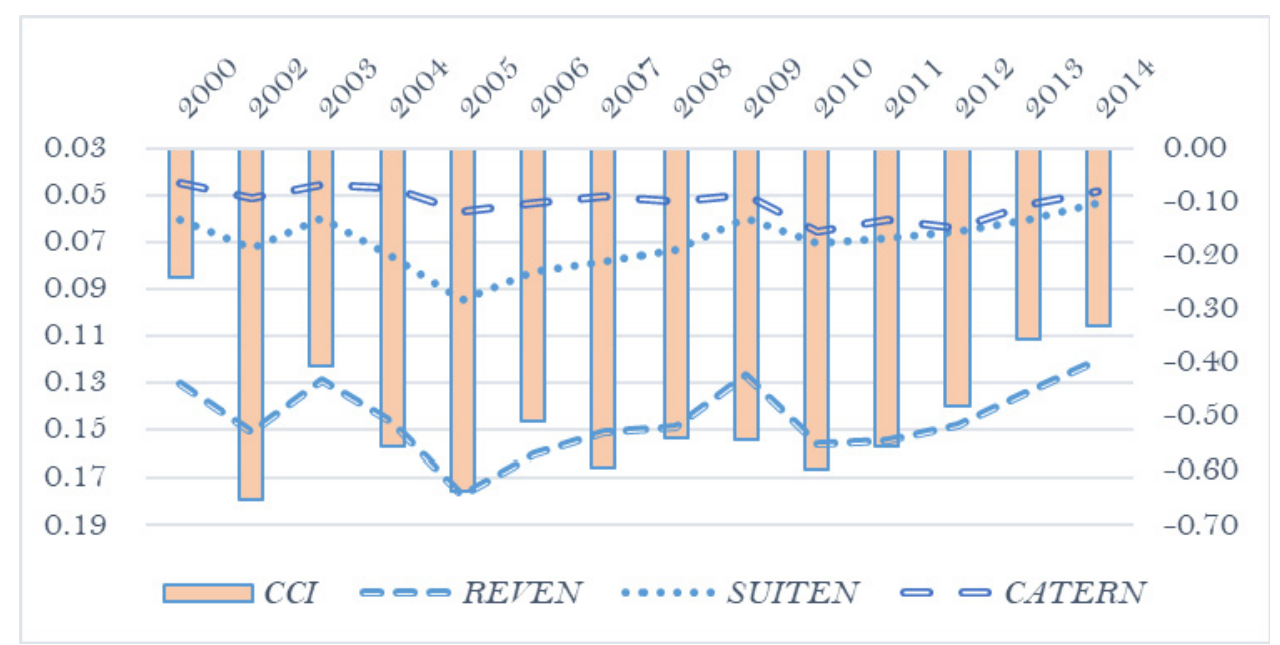

Figure 1. The analysis of Corruption Control Index $(C C I)$ and total revenue of five-star hotels in China

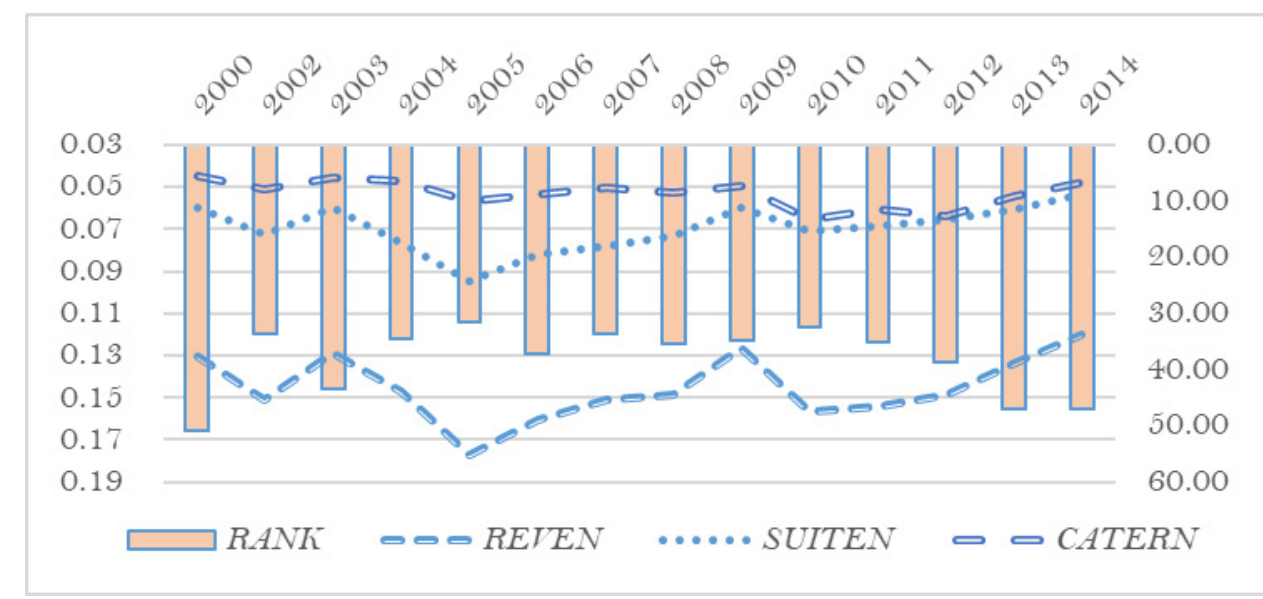

Figure 2. The analysis of China's Corruption Percentage Ranking (RANK) and total revenue of five-star hotels in China 


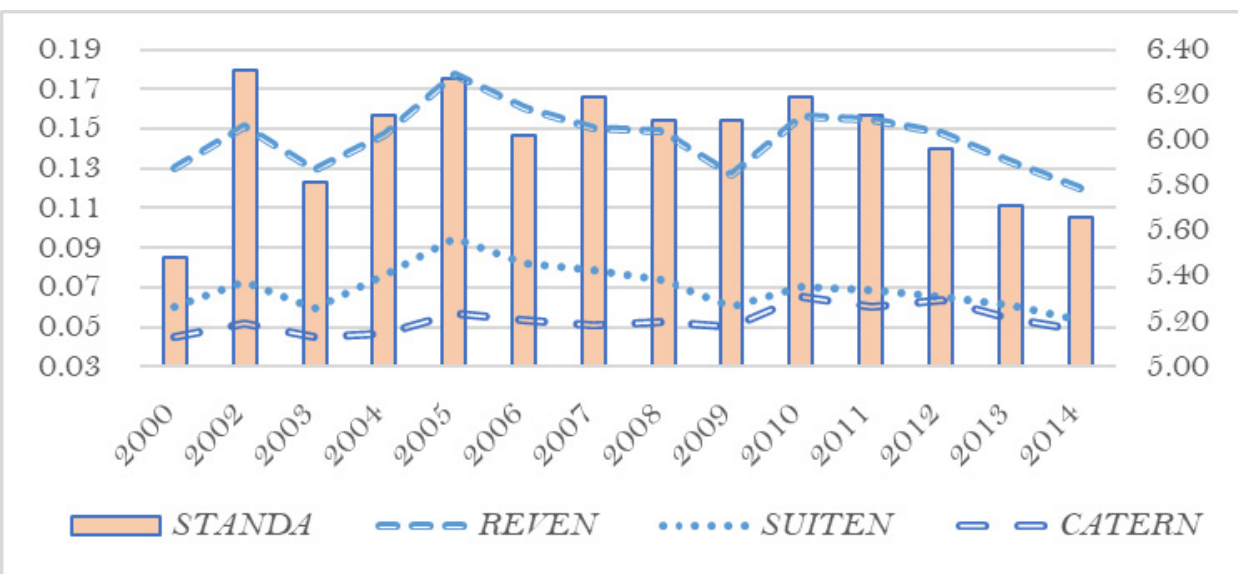

Figure 3. The analysis of standardized corruption control index (STANDA) and total revenue of five-star hotels in China

Table 2 shows the correlation between the degree of corruption and the growth of the five-star hotel industry in China. In Table 2, the corruption control index $(C C I)$, Corruption Percentage Ranking $(R A N K)$ has a significant negative correlation with five-star hotel industry growth (REVEN, SUITEN, CATERN), and the significant level is above 5\%. The standardized corruption control index (STANDA) was significantly positively correlated with five-star hotel industry growth (REVEN, SUITEN, CATERN), and the significant level was above $10 \%$. The results show that the degree of national corruption has a positive effect on the growth of the national five-star hotel industry, which verified hypothesis 1 .

Table 2. Correlation analysis of corruption degree in china and five-star hotel revenue

\begin{tabular}{lllllll}
\hline & REVEN & SUITEN & CATERN & CCI & RANK & STANDA \\
\hline \multirow{2}{*}{ REVEN } & $\mathbf{1 . 0 0 0}$ & $0.889^{* * *}$ & $0.603^{* *}$ & $-0.725^{* * *}$ & $-0.733^{* * *}$ & $0.704^{* * *}$ \\
& $\mathbf{( 0 . 0 0 0 )}$ & $(0.000)$ & $(0.022)$ & $(0.003)$ & $(0.003)$ & $(0.005)$ \\
SUITEN & $0.921^{* * *}$ & $\mathbf{1 . 0 0 0}$ & 0.370 & $-0.700^{* * *}$ & $-0.722^{* * *}$ & $0.698^{* * *}$ \\
& $(0.000)$ & $\mathbf{( 0 . 0 0 0 )}$ & $(0.193)$ & $(0.005)$ & $(0.004)$ & $(0.006)$ \\
CATERN & $0.576^{* *}$ & 0.325 & $\mathbf{1 . 0 0 0}$ & $-0.509^{* *}$ & $-0.533^{* *}$ & $0.488^{*}$ \\
& $(0.031)$ & $(0.257)$ & $\mathbf{( 0 . 0 0 0 )}$ & $(0.063)$ & $(0.049)$ & $(0.077)$ \\
CCI & $-0.761^{* * *}$ & $-0.721^{* * *}$ & $-0.551^{* *}$ & $\mathbf{1 . 0 0 0}$ & $0.963^{* * *}$ & $-0.998^{* * *}$ \\
& $(0.002)$ & $(0.004)$ & $(0.041)$ & $\mathbf{( 0 . 0 0 0 )}$ & $(0.000)$ & $(0.000)$ \\
\multirow{2}{*}{ RANK } & $-0.768^{* * *}$ & $-0.733^{* * *}$ & $-0.570^{* *}$ & $0.983^{* * *}$ & $\mathbf{1 . 0 0 0}$ & $-0.965^{* * *}$ \\
& $(0.001)$ & $(0.003)$ & $(0.033)$ & $(0.000)$ & $\mathbf{( 0 . 0 0 0 )}$ & $(0.000)$ \\
\multirow{2}{*}{ STANDA } & $0.750^{* * *}$ & $0.713^{* * *}$ & $0.535^{* *}$ & $-1.000^{* * *}$ & $-0.982^{* * *}$ & $\mathbf{1 . 0 0 0}$ \\
& $(0.002)$ & $(0.004)$ & $(0.049)$ & $(0.000)$ & $(0.000)$ & $\mathbf{( 0 . 0 0 0 )}$ \\
\hline
\end{tabular}

Note. The upper triangle is Spearman correlation coefficient, the lower triangle is Pearson correlation coefficient. $* * *, * *, *$ respectively indicate that the significant level is $1 \%, 5 \%$ and $10 \%$. P value is in parentheses. 
4.3 Regional Anti-Corruption, Marketization Process and the Development of Five-Star Hotel Industry

Tables 3 to 5 discuss the relationship between anti-corruption policy, marketization process and revenue of five-star hotel. ANTICOR represents three anti-corruption policy variables (ACORRU, POLICY, ITEM).

The Anti-Corruption Rule (ACORRU) is negatively and significantly associated with the five-star hotel revenue (REVE), room revenue (SUITE), and food and beverage income $(C A T E R)$. The number of anti-corruption policies $(P O L I C Y)$ is negatively and significantly related to the catering income of five-star hotels (CATER), but no longer has significant relationship with the total revenue of five-star hotels (REVE) and the room revenue (SUITE). The anti-corruption policy involves the terms of the five-star hotel (ITEM) is significantly and negatively associated with the five-star hotel's total revenue (REVE), room revenue (SUITE), and catering revenue (CATER). The regression results show that, compared with the number of anti-corruption policies (POLICY), the number of terms of five-star hotels involved in the anti-corruption policy (ITEM) has a greater negative impact on the revenue of five-star hotels. The national anti-corruption efforts affect the business scope of five-star hotels in an all-round way. The rooms and catering business are affected by anti-corruption to varying degrees, showing a decline in income.

The level of marketization (MARKET) is positively and significantly related to the growth of the five-star hotel industry, which indicates that the perfect market-oriented system has played a continuous role in promoting the growth of five-star hotels. The coefficients on the interaction terms between the anti-corruption policy variables (ACORRU, ITEM) and marketization variable (MARKET) are all significant and positive. The coefficients on the interaction terms between the number of anti-corruption policies (POLICY) and marketization $(M A R K E T)$ is only positively and significantly related to the five-star hotel catering income $(C A T E R)$ at $10 \%$ level. The regression results basically verified the important role played by market forces in the shrinking of the five-star hotel business under the impact of anti-corruption. In general, the more anti-corruption policies, the greater the country's efforts to combat corruption, the more serious the decline in the income of five-star hotels, but the well market environment can inhibit the negative impact of anti-corruption policies on the growth of five-star hotels.

Table 3. Anti-corruption rules, marketization level and total revenue of five-star hotels

\begin{tabular}{lllllll}
\hline & $(1)$ & $(2)$ & $(3)$ & $(4)$ & $(5)$ & $(6)$ \\
& ACORRU & ACORRU & POLICY & POLICY & ITEM & ITEM \\
\hline$C$ & $-0.933^{* * *}$ & -0.047 & $-0.924^{* * *}$ & $-0.917^{* * *}$ & $-0.938^{* * *}$ & $-0.944^{* * *}$ \\
& $(-8.297)$ & $(-0.088)$ & $(-8.288)$ & $(-8.524)$ & $(-8.643)$ & $(-8.804)$ \\
ANTICOR & $-0.011^{* * *}$ & $-0.004^{*}$ & -0.001 & -0.001 & $-0.016^{* * *}$ & $-0.010^{* * *}$ \\
& $(-2.984)$ & $(-1.673)$ & $(-0.867)$ & $(-0.794)$ & $(-4.630)$ & $(-2.605)$ \\
MARKET & $0.047^{* *}$ & $0.794^{* * *}$ & $0.071^{* * *}$ & $0.007^{* *}$ & $0.046^{* *}$ & $0.012^{* * *}$ \\
& $(2.060)$ & $(4.006)$ & $(3.969)$ & $(2.139)$ & $(2.053)$ & $(4.358)$ \\
\hline
\end{tabular}




\begin{tabular}{|c|c|c|c|c|c|c|}
\hline \multicolumn{2}{|l|}{$A N T I C O R$} & \multicolumn{2}{|l|}{$0.326^{* * *}$} & \multicolumn{2}{|l|}{0.002} & \multirow{2}{*}{$\begin{array}{l}0.009^{* * *} \\
(3.673)\end{array}$} \\
\hline$\times M A R K E T$ & & $(6.560)$ & & $(0.450)$ & & \\
\hline \multirow[t]{2}{*}{ FIX } & $-0.027^{* * *}$ & -0.013 & $-0.022^{* * *}$ & $-0.021^{* * *}$ & $-0.027^{* * *}$ & $-0.027^{* * *}$ \\
\hline & $(-7.580)$ & $(-1.169)$ & $(-7.138)$ & $(-6.585)$ & $(-7.906)$ & $(-7.844)$ \\
\hline \multirow[t]{2}{*}{ CONSUM } & $0.388^{* * *}$ & $0.500^{* *}$ & $0.385^{* * *}$ & $0.396^{* * *}$ & $0.390^{* * *}$ & $0.402^{* * *}$ \\
\hline & $(5.777)$ & $(2.066)$ & $(5.686)$ & $(5.712)$ & $(5.798)$ & $(5.773)$ \\
\hline \multirow[t]{2}{*}{$U R B A N$} & $0.414^{* * *}$ & $0.583^{* *}$ & $0.410^{* * *}$ & $0.403^{* * *}$ & $0.417^{* * *}$ & $0.414^{* * *}$ \\
\hline & $(10.469)$ & $(2.296)$ & $(10.980)$ & (11.144) & $(10.530)$ & (10.669) \\
\hline \multirow[t]{2}{*}{$C P I$} & $0.163^{* *}$ & $0.867^{* * *}$ & $0.148^{* *}$ & $0.137^{*}$ & $0.162^{* *}$ & $0.158^{* *}$ \\
\hline & (2.329) & $(2.595)$ & $(2.198)$ & $(1.866)$ & $(2.569)$ & $(2.402)$ \\
\hline \multirow[t]{2}{*}{ TOUR } & $0.007^{* *}$ & 0.027 & $0.007^{* *}$ & $0.007^{* *}$ & $0.008^{* *}$ & $0.008^{* *}$ \\
\hline & (1.991) & $(1.008)$ & (1.995) & $(1.970)$ & $(2.098)$ & $(2.110)$ \\
\hline \multirow[t]{2}{*}{ FOUND } & $0.048^{* * *}$ & $-0.039^{* *}$ & $0.047^{* * *}$ & $0.048^{* * *}$ & $0.048^{* * *}$ & $0.049^{* * *}$ \\
\hline & $(10.252)$ & $(-2.513)$ & $(10.483)$ & $(10.340)$ & (10.334) & $(10.320)$ \\
\hline \multirow[t]{2}{*}{ VISITOR } & $0.001^{*}$ & 0.004 & $0.002^{* *}$ & $0.002^{* *}$ & $0.001^{*}$ & $0.001^{*}$ \\
\hline & (1.794) & $(0.622)$ & $(2.054)$ & $(2.241)$ & (1.682) & $(1.735)$ \\
\hline \multirow[t]{2}{*}{$S E R V$} & $-0.040^{* * *}$ & $-0.364^{* * *}$ & $-0.039^{* * *}$ & $-0.039^{* * *}$ & $-0.041^{* * *}$ & $-0.410^{* * *}$ \\
\hline & $(-5.833)$ & $(-4.244)$ & $(-5.861)$ & $(-6.150)$ & $(-5.964)$ & $(-6.049)$ \\
\hline \multirow[t]{2}{*}{ GROUP } & $0.018^{* * *}$ & 0.010 & $0.019^{* * *}$ & $0.018^{* *}$ & $0.018^{* * *}$ & $0.018^{* * *}$ \\
\hline & $(5.248)$ & $(0.842)$ & (5.784) & $(5.228)$ & (5.303) & (4.991) \\
\hline \multirow[t]{2}{*}{$M A R R I$} & $-1.967^{* * *}$ & 3.774 & $-1.617^{* * *}$ & $-1.501^{* * *}$ & $-1.896^{* * *}$ & $-1.753^{* * *}$ \\
\hline & $(-4.132)$ & $(1.487)$ & $(-3.283)$ & $(-2.925)$ & $(-3.991)$ & $(-3.650)$ \\
\hline$Y E A R$ & $Y E S$ & $Y E S$ & $Y E S$ & YES & $Y E S$ & $Y E S$ \\
\hline Adj. $R^{2}$ & 0.553 & 0.811 & 0.547 & 0.536 & 0.560 & 0.552 \\
\hline$F$ & $27.077^{* * *}$ & $36.472^{* * *}$ & $26.430^{* * *}$ & $24.117^{* * *}$ & $27.795^{* * *}$ & $25.719^{* * *}$ \\
\hline$N$ & 422 & 422 & 422 & 422 & 422 & 422 \\
\hline
\end{tabular}

Note: ${ }^{* * *},{ }^{* *},{ }^{*}$ respectively indicate that the significant level is $1 \%, 5 \%$ and $10 \%$.

Table 4. Anti-corruption rules, marketization level and room revenue of five-star hotels

\begin{tabular}{lllllll}
\hline & $(1)$ & $(2)$ & $(3)$ & $(4)$ & $(5)$ & $(6)$ \\
& ACORRU & ACORRU & POLICY & POLICY & ITEM & ITEM \\
\hline$C$ & $-0.053^{* * *}$ & 0.362 & $-0.518^{* * *}$ & $-0.512^{* * *}$ & $-0.534^{* * *}$ & $-0.528^{* * *}$ \\
& $(-8.599)$ & $(1.543)$ & $(-7.708)$ & $(-7.423)$ & $(-9.290)$ & $(-8.936)$ \\
ANTICOR & $-0.335^{* * *}$ & $-0.019^{* * *}$ & -0.001 & -0.001 & $-0.196^{* * *}$ & $-0.017^{* *}$ \\
& $(-5.242)$ & $(-3.874)$ & $(-0.807)$ & $(-0.742)$ & $(-2.752)$ & $(-1.978)$ \\
MARKET & $0.069^{* * *}$ & $0.442^{* * *}$ & $0.079^{* * *}$ & $0.069^{* * *}$ & $0.067^{* * *}$ & $0.067^{* * *}$ \\
& $(5.108)$ & $(5.017)$ & $(5.781)$ & $(3.554)$ & $(5.261)$ & $(4.442)$ \\
\hline
\end{tabular}




\begin{tabular}{|c|c|c|c|c|c|c|}
\hline \multicolumn{2}{|l|}{$A N T I C O R$} & \multicolumn{2}{|l|}{$0.012^{* *}$} & \multicolumn{2}{|l|}{0.000} & $0.000^{* * *}$ \\
\hline \multicolumn{2}{|l|}{$\times M A R K E T$} & \multicolumn{2}{|l|}{$(2.548)$} & \multicolumn{2}{|l|}{$(0.156)$} & $(3.162)$ \\
\hline \multirow[t]{2}{*}{$F I X$} & $-0.019^{* * *}$ & 0.001 & $-0.016^{* * *}$ & $-0.015^{* * *}$ & $-0.020^{* * *}$ & $-0.020^{* * *}$ \\
\hline & $(-10.740)$ & $(0.177)$ & $(-8.262)$ & $(-7.810)$ & $(-11.939)$ & $(-12.144)$ \\
\hline \multirow[t]{2}{*}{ CONSUM } & $0.226^{* * *}$ & $0.190^{*}$ & $0.224^{* * *}$ & $0.227^{* * *}$ & $0.226^{* * *}$ & $0.226^{* * *}$ \\
\hline & $(5.748)$ & $(1.765)$ & $(5.673)$ & $(5.811)$ & $(5.810)$ & $(5.846)$ \\
\hline \multirow[t]{2}{*}{$U R B A N$} & $0.333^{* * *}$ & $0.234^{* *}$ & $0.331^{* * *}$ & $0.330^{* * *}$ & $0.335^{* * *}$ & $0.337^{* * *}$ \\
\hline & $(25.954)$ & $(2.069)$ & $(24.754)$ & $(23.607)$ & $(27.231)$ & $(26.802)$ \\
\hline \multirow[t]{2}{*}{$C P I$} & 0.025 & 0.112 & 0.010 & 0.004 & 0.025 & 0.018 \\
\hline & $(0.359)$ & $(0.753)$ & $(0.133)$ & $(0.050)$ & $(0.410)$ & $(0.277)$ \\
\hline \multirow[t]{2}{*}{ TOUR } & $0.020^{* * *}$ & 0.015 & $0.019^{* * *}$ & $0.019^{* * *}$ & $0.020^{* * *}$ & $0.020^{* * *}$ \\
\hline & $(11.522)$ & $(1.216)$ & $(11.210)$ & $(11.233)$ & (11.739) & $(11.865)$ \\
\hline \multirow[t]{2}{*}{ FOUND } & $0.027^{* * *}$ & $-0.028^{* * *}$ & $0.027^{* * *}$ & $0.027^{* * *}$ & $0.028^{* * *}$ & $0.028^{* * *}$ \\
\hline & (12.309) & $(-4.079)$ & (11.858) & (11.919) & $(12.364)$ & $(12.371)$ \\
\hline \multirow[t]{2}{*}{ VISITOR } & $-0.001^{* * *}$ & 0.002 & $-0.001^{* * *}$ & $-0.001^{* * *}$ & $-0.001^{* * *}$ & $-0.001^{* * *}$ \\
\hline & $(-3.447)$ & $(0.762)$ & $(-2.882)$ & $(-2.767)$ & $(-3.732)$ & $(-3.762)$ \\
\hline \multirow[t]{2}{*}{$S E R V$} & $-0.019^{* * *}$ & $-0.170^{* * *}$ & $-0.020^{* * *}$ & $-0.020^{* * *}$ & $-0.020^{* * *}$ & $-0.020^{* * *}$ \\
\hline & $(-5.119)$ & $(-4.451)$ & $(5.059)$ & $(-5.377)$ & $(-5.280)$ & $(-5.427)$ \\
\hline \multirow[t]{2}{*}{ GROUP } & -0.002 & 0.004 & -0.002 & -0.002 & -0.002 & -0.003 \\
\hline & $(-1.221)$ & $(0.731)$ & $(-1.108)$ & $(-1.231)$ & $(-1.276)$ & $(-1.398)$ \\
\hline \multirow[t]{2}{*}{$M A R R I$} & $-1.122^{* * *}$ & $4.855^{* * *}$ & $-0.953^{* * *}$ & $-0.889^{* * *}$ & $-1.081^{* * *}$ & $-1.054^{* * *}$ \\
\hline & $(-3.035)$ & $(4.300)$ & $(-3.169)$ & $(-2.945)$ & $(-2.991)$ & $(-2.906)$ \\
\hline$Y E A R$ & $Y E S$ & $Y E S$ & $Y E S$ & $Y E S$ & $Y E S$ & YES \\
\hline Adj. $R^{2}$ & 0.535 & 0.906 & 0.540 & 0.538 & 0.538 & 0.539 \\
\hline$F$ & $25.174^{* * *}$ & $80.559^{* * *}$ & $25.715^{* * *}$ & $24.366^{* * *}$ & $25.588^{* * *}$ & $24.463^{* * *}$ \\
\hline$N$ & 422 & 422 & 422 & 422 & 422 & 422 \\
\hline
\end{tabular}

Note: ${ }^{* * *},{ }^{* *},{ }^{*}$ respectively indicate that the significant level is $1 \%, 5 \%$ and $10 \%$.

Table 5. Anti-corruption rules, marketization level and food and beverage revenue of five-star hotels

\begin{tabular}{lllllll}
\hline & $(1)$ & $(2)$ & $(3)$ & $(4)$ & $(5)$ & $(6)$ \\
& ACORRU & ACORRU & POLICY & POLICY & ITEM & ITEM \\
\hline$C$ & $-0.446^{* * *}$ & 0.212 & $-0.442^{* * *}$ & $-0.473^{* * *}$ & $-0.447^{* * *}$ & $-0.442^{* * *}$ \\
& $(-8.804)$ & $(1.475)$ & $(-10.620)$ & $(-10.990)$ & $(-8.480)$ & $(-8.483)$ \\
ANTICOR & $-0.002^{* * *}$ & $-0.0004^{*}$ & $-0.001^{* * *}$ & $-0.004^{*}$ & $-0.009^{* *}$ & -0.004 \\
& $(-2.951)$ & $(-1.879)$ & $(-2.585)$ & $(-1.755)$ & $(-2.020)$ & $(-0.852)$ \\
\hline
\end{tabular}




\begin{tabular}{|c|c|c|c|c|c|c|}
\hline$M A R K E T$ & $\begin{array}{l}0.027^{* * *} \\
(2.749)\end{array}$ & $\begin{array}{l}0.193^{* * *} \\
(3.570)\end{array}$ & $\begin{array}{l}0.032^{* * *} \\
(3.511)\end{array}$ & $\begin{array}{l}0.057^{* * *} \\
(3.009)\end{array}$ & $\begin{array}{l}0.025^{* *} \\
(2.552)\end{array}$ & $\begin{array}{l}0.033^{* *} \\
(2.378)\end{array}$ \\
\hline ANTICOR & & $0.062^{* *}$ & & $0.002^{*}$ & & $0.005^{* *}$ \\
\hline$\times M A R K E T$ & & (2.159) & & (1.799) & & $(2.467)$ \\
\hline \multirow[t]{2}{*}{$F I X$} & $-0.011^{* * *}$ & 0.000 & $-0.010^{* * *}$ & $-0.010^{* * *}$ & $-0.011^{* * *}$ & $-0.012^{* * *}$ \\
\hline & $(-6.477)$ & $(0.123)$ & $(-4.876)$ & $(-5.164)$ & $(-7.714)$ & $(-8.085)$ \\
\hline \multirow[t]{2}{*}{ CONSUM } & $0.172^{* * *}$ & 0.018 & $0.174^{* * *}$ & $0.168^{* * *}$ & $0.171^{* * *}$ & $0.168^{* * *}$ \\
\hline & $(5.865)$ & $(0.271)$ & $(5.891)$ & $(5.876)$ & $(5.872)$ & $(5.820)$ \\
\hline \multirow[t]{2}{*}{$U R B A N$} & $0.242^{* * *}$ & $0.178^{* *}$ & $0.241^{* * *}$ & $0.244^{* * *}$ & $0.243^{* * *}$ & $0.244^{* * *}$ \\
\hline & $(23.244)$ & $(2.563)$ & $(25.079)$ & $(25.257)$ & $(23.842)$ & $(23.456)$ \\
\hline \multirow[t]{2}{*}{$C P I$} & 0.037 & 0.069 & 0.025 & 0.020 & 0.037 & 0.033 \\
\hline & $(0.957)$ & $(0.756)$ & $(0.903)$ & $(0.749)$ & $(0.947)$ & $(0.838)$ \\
\hline \multirow[t]{2}{*}{ TOUR } & $0.005^{* * *}$ & 0.007 & $0.005^{* * *}$ & $0.006^{* * *}$ & $0.006^{* * *}$ & $0.006^{* * *}$ \\
\hline & $(4.574)$ & $(0.937)$ & $(4.793)$ & $(4.985)$ & $(4.821)$ & (4.904) \\
\hline \multirow[t]{2}{*}{ FOUND } & $0.025^{* * *}$ & $-0.011^{* * *}$ & $0.026^{* * *}$ & $0.026^{* * *}$ & $0.026^{* * *}$ & $0.026^{* * *}$ \\
\hline & $(16.751)$ & $(-2.655)$ & $(16.902)$ & $(16.721)$ & $(16.620)$ & $(16.582)$ \\
\hline \multirow[t]{2}{*}{ VISITOR } & $-0.001^{*}$ & 0.002 & $-0.001^{*}$ & $-0.001^{*}$ & $-0.001^{*}$ & $-0.001^{*}$ \\
\hline & $(-1.761)$ & $(1.031)$ & $(-1.758)$ & $(-1.880)$ & $(-1.753)$ & $(-1.751)$ \\
\hline \multirow[t]{2}{*}{$S E R V$} & $-0.017^{* * *}$ & $-0.087^{* * *}$ & $-0.017^{* * *}$ & $-0.016^{* * *}$ & $-0.017^{* * *}$ & $-0.017^{* * *}$ \\
\hline & $(-5.802)$ & $(-3.731)$ & $(-5.900)$ & $(-5.768)$ & $(-5.926)$ & $(-5.850)$ \\
\hline \multirow[t]{2}{*}{ GROUP } & $0.007^{* * *}$ & $0.002^{* *}$ & $0.007^{* * *}$ & $0.007^{* * *}$ & $0.007^{* * *}$ & $0.007^{* * *}$ \\
\hline & (3.939) & $(0.648)$ & (4.099) & $(4.134)$ & $(3.900)$ & (3.877) \\
\hline \multirow[t]{2}{*}{$M A R R I$} & $-1.256^{* * *}$ & $1.655^{* *}$ & $-1.106^{* * *}$ & $-1.134^{* * *}$ & $-1.261^{* * *}$ & $-1.285^{* * *}$ \\
\hline & $(-5.094)$ & $(2.390)$ & $(-5.158)$ & $(-5.265)$ & $(-5.098)$ & $(-5.201)$ \\
\hline$Y E A R$ & $Y E S$ & $Y E S$ & $Y E S$ & $Y E S$ & $Y E S$ & $Y E S$ \\
\hline $\operatorname{Adj} . R^{2}$ & 0.707 & 0.886 & 0.710 & 0.711 & 0.708 & 0.707 \\
\hline$F$ & $51.738^{* * *}$ & $65.166^{* * *}$ & $52.521^{* * *}$ & $50.220^{* * *}$ & $51.928^{* * *}$ & $49.384^{* * *}$ \\
\hline$N$ & 422 & 422 & 422 & 422 & 422 & 422 \\
\hline
\end{tabular}

Note: ${ }^{* * *},{ }^{* *},{ }^{*}$ respectively indicate that the significant level is $1 \%, 5 \%$ and $10 \%$.

Tables 6 to 8 provide the regression results of regional anti-corruption intensity, marketization levels and five-star hotel revenue. ANTICOR represents three anti-corruption effect variables (FIL, SUSP, CAD). The number of corruption filings (FIL), corruption (SUSP) are negatively and significantly associated with five-star hotel total revenue (REVE), room income (SUITE), and food income (CATER). The number of cadres above the county level (CAD) against the anti-corruption investigation are negatively and significantly related to the total revenue of the five-star hotel (REVE) and the room revenue (SUITE). In table 8, the estimated coefficients on CAD is insignificantly negative in Column (5), and significantly negative in 
Column (6), showing that the number of cadres above the county level $(C A D)$ has significantly negative impacts on five-star hotel revenue, especially on room revenue (SUITE).

The coefficients on the interaction terms between marketization (MARKET) and Anti-Corruption Intensity variables $(F I L, S U S P, C A D)$ are all significant and positive. The regression results show that the greater the anti-corruption efforts, the more serious the decline in the revenue of five-star hotels will be; but in areas with high marketization levels, the effect of anti-corruption on the growth of the five-star hotel industry is weakened. Anti-corruption cut off the traditional way of relying on government consumption development for five-star hotels. To recover from the depression which caused by anti-corruption, five-star hotels should adjust their strategic positioning and development strategies, optimize product and service structure, integrate into the marketization process of China with the attitude of market-oriented competitors, and pay close attention to different types of consumer demand in the market. In addition, consumption levels, urbanization levels, and infrastructure levels are positively and significantly associated with five-star hotel revenues.

Table 6. Anti-corruption intensity, marketization level and total revenue of five-star hotels

\begin{tabular}{|c|c|c|c|c|c|c|}
\hline & (1) & (2) & (3) & (4) & (5) & (6) \\
\hline & $F I L$ & $F I L$ & SUSP & $S U S P$ & $C A D$ & $C A D$ \\
\hline \multirow[t]{2}{*}{$C$} & $-0.545^{* * *}$ & $-0.500^{* *}$ & -0.296 & -0.182 & -0.833 & $-0.618^{* *}$ \\
\hline & $(-2.810)$ & $(-1.965)$ & $(-1.491)$ & $(-0.706)$ & $(-1.375)$ & $(-1.965)$ \\
\hline \multirow[t]{2}{*}{ ANTICOR } & $-0.025^{* * *}$ & $-0.027^{* *}$ & $-0.035^{* * *}$ & $-0.042^{* * *}$ & $-0.005^{* *}$ & $-0.036^{*}$ \\
\hline & $(-2.879)$ & $(-2.233)$ & $(-5.346)$ & $(-2.933)$ & $(-1.984)$ & $(-1.797)$ \\
\hline \multirow[t]{2}{*}{ MARKET } & $0.288^{* * *}$ & $0.011^{* *}$ & -0.020 & $0.014^{* * *}$ & $0.008^{* *}$ & $0.008^{*}$ \\
\hline & $(3.421)$ & $(2.407)$ & $(-0.718)$ & $(3.755)$ & $(2.265)$ & $(1.906)$ \\
\hline ANTICOR & & $0.307^{* * *}$ & & $0.011^{* * *}$ & & $0.219^{* *}$ \\
\hline$\times M A R K E T$ & & $(4.984)$ & & $(3.590)$ & & $(2.503)$ \\
\hline \multirow[t]{2}{*}{$F I X$} & $-0.024^{* * *}$ & $-0.024^{* * *}$ & $-0.030^{* * *}$ & $-0.031^{* * *}$ & $-0.061^{* *}$ & $-0.040^{* * *}$ \\
\hline & $(-7.880)$ & $(-4.791)$ & $(-6.968)$ & $(-5.676)$ & $(-2.458)$ & $(-4.190)$ \\
\hline \multirow[t]{2}{*}{ CONSUM } & $0.395^{* * *}$ & $0.375^{* * *}$ & $0.329^{* * *}$ & $0.286^{* * *}$ & 0.188 & 0.191 \\
\hline & $(5.874)$ & $(5.452)$ & $(5.412)$ & $(4.062)$ & $(0.403)$ & $(1.304)$ \\
\hline \multirow[t]{2}{*}{$U R B A N$} & $0.406^{* * *}$ & $0.409^{* * *}$ & $0.431^{* * *}$ & $0.432^{* * *}$ & $0.704^{* * *}$ & $0.571^{* * *}$ \\
\hline & $(9.881)$ & $(8.681)$ & (7.009) & $(7.886)$ & $(3.804)$ & $(6.194)$ \\
\hline \multirow[t]{2}{*}{$C P I$} & -0.107 & -0.129 & -0.145 & -0.190 & -0.055 & 0.228 \\
\hline & $(-0.755)$ & $(-0.623)$ & $(-0.894)$ & $(-0.924)$ & $(-0.115)$ & $(0.941)$ \\
\hline \multirow[t]{2}{*}{ TOUR } & 0.002 & 0.002 & -0.000 & 0.000 & 0.010 & 0.010 \\
\hline & $(0.508)$ & $(0.340)$ & $(-0.118)$ & $(0.008)$ & $(0.448)$ & $(0.665)$ \\
\hline
\end{tabular}




\begin{tabular}{lllllll}
\hline FOUND & $0.045^{* * *}$ & $0.045^{* * *}$ & $0.039^{* * *}$ & $0.040^{* * *}$ & $0.057^{* *}$ & $0.030^{* * *}$ \\
& $(10.220)$ & $(8.993)$ & $(8.162)$ & $(7.091)$ & $(2.189)$ & $(2.766)$ \\
VISITOR & 0.001 & 0.001 & 0.000 & 0.000 & -0.001 & 0.004 \\
& $(1.371)$ & $(0.723)$ & $(0.071)$ & $(0.092)$ & $(-0.199)$ & $(1.157)$ \\
SERV & -0.011 & -0.011 & -0.009 & -0.010 & -0.087 & $-0.045^{* *}$ \\
& $(-1.037)$ & $(-0.973)$ & $(-0.923)$ & $(-0.758)$ & $(-1.002)$ & $(-1.993)$ \\
GROUP & $0.017^{* * *}$ & $0.018^{* * *}$ & $0.017^{* * *}$ & $0.018^{* * *}$ & 0.021 & 0.002 \\
& $(5.183)$ & $(3.567)$ & $(4.701)$ & $(3.539)$ & $(0.998)$ & $(0.292)$ \\
MARRI & $-0.841^{*}$ & -1.045 & $-1.149^{*}$ & -1.601 & 12.678 & $6.486^{* * *}$ \\
& $(-1.720)$ & $(-0.827)$ & $(-1.898)$ & $(-1.172)$ & $(1.232)$ & $(3.669)$ \\
YEAR & $Y E S$ & $Y E S$ & $Y E S$ & $Y E S$ & $Y E S$ & $Y E S$ \\
Adj. $R^{2}$ & 0.502 & 0.503 & 0.527 & 0.536 & 0.349 & 0.349 \\
$F$ & $21.181^{* * *}$ & $20.383^{* * *}$ & $20.017^{* * *}$ & $19.792^{* * *}$ & $10.162^{* * *}$ & $0.741^{* * *}$ \\
$N$ & 422 & 422 & 359 & 359 & 360 & 360 \\
\hline
\end{tabular}

Note: ${ }^{* * *},{ }^{* *},{ }^{*}$ respectively indicate that the significant level is $1 \%, 5 \%$ and $10 \%$.

Table 7. Anti-corruption intensity, marketization level and room revenue of five-star hotels

\begin{tabular}{lllllll}
\hline & $(1)$ & $(2)$ & $(3)$ & $(4)$ & $(5)$ & $(6)$ \\
& $F I L$ & $F I L$ & SUSP & SUSP & CAD & $C A D$ \\
\hline C & $-0.149^{* *}$ & 0.002 & -0.051 & 0.121 & 0.019 & -0.138 \\
ANTICOR & $(-1.825)$ & $(0.010)$ & $(-0.618)$ & $(0.719)$ & $(0.051)$ & $(-0.935)$ \\
& $-0.028^{* * *}$ & $-0.034^{* * *}$ & $-0.038^{* * *}$ & $-0.050^{* * *}$ & $-0.032^{* *}$ & $-0.040^{* * *}$ \\
MARKET & $(-6.800)$ & $(-4.515)$ & $(-8.891)$ & $(-5.631)$ & $(-2.030)$ & $(-4.931)$ \\
& $0.039^{* * *}$ & -0.074 & 0.000 & $6.031^{* *}$ & $0.041^{* * *}$ & $0.030^{* * *}$ \\
ANTICOR & $(2.666)$ & $(-1.443)$ & $(0.025)$ & $(1.988)$ & $(4.633)$ & $(5.681)$ \\
$\times$ MARKET & & $0.029^{* * *}$ & & $0.046^{* *}$ & & $0.212^{* * *}$ \\
FIX & & $(2.806)$ & & $(2.470)$ & & $(5.398)$ \\
& $-0.019^{* * *}$ & $-0.021^{* * *}$ & $-0.022^{* * *}$ & $-0.023^{* * *}$ & $-0.047^{* * *}$ & $-0.021^{* * *}$ \\
CONSUM & $(-15.179)$ & $(-6.714)$ & $(-10.081)$ & $(-6.381)$ & $(-2.823)$ & $(5.892)$ \\
& $0.243^{* * *}$ & $0.187^{* * *}$ & $0.227^{* * *}$ & $0.160^{* * *}$ & 0.080 & $0.206^{* * *}$ \\
URBAN & $(6.631)$ & $(4.248)$ & $(6.066)$ & $(3.411)$ & $(0.250)$ & $(4.488)$ \\
& $0.361^{* * *}$ & $0.369^{* * *}$ & $0.381^{* * *}$ & $0.380^{* * *}$ & $0.625^{* * *}$ & $0.373^{* * *}$ \\
CPI & $(28.319)$ & $(12.984)$ & $(17.655)$ & $(11.670)$ & $(3.638)$ & $(12.031)$ \\
& $-0.224^{* * *}$ & $-0.327^{* *}$ & $-0.215^{* * *}$ & $-0.306^{* *}$ & $-0.653^{* *}$ & $-0.243^{*}$ \\
TOUR & $(-3.343)$ & $(-2.465)$ & $(-3.382)$ & $(-2.244)$ & $(-2.116)$ & $(-1.787)$ \\
& $0.012^{* * *}$ & $0.013^{* * *}$ & $0.014^{* * *}$ & $0.014^{* * *}$ & 0.031 & $0.022^{* * *}$ \\
& $(7.419)$ & $(3.666)$ & $(8.679)$ & $(3.523)$ & $(1.571)$ & $(6.385)$ \\
\hline
\end{tabular}




\begin{tabular}{lllllll}
\hline FOUND & $0.022^{* * *}$ & $0.023^{* * *}$ & $0.018^{* * *}$ & $0.021^{* * *}$ & $0.032^{*}$ & $0.027^{* * *}$ \\
& $(10.074)$ & $(7.318)$ & $(7.176)$ & $(5.807)$ & $(1.877)$ & $(8.308)$ \\
VISITOR & $-0.002^{* * *}$ & $-0.002^{* *}$ & $-0.003^{* * *}$ & $-0.003^{* * *}$ & -0.004 & -0.001 \\
& $(-7.718)$ & $(-2.184)$ & $(-6.624)$ & $(-3.152)$ & $(-1.104)$ & $(-1.553)$ \\
SERV & $0.012^{* *}$ & $0.014^{*}$ & $0.016^{* * *}$ & $0.024^{* * *}$ & -0.037 & -0.007 \\
& $(1.966)$ & $(1.834)$ & $(2.637)$ & $(2.798)$ & $(-0.646)$ & $(-1.395)$ \\
GROUP & -0.002 & -0.001 & $-0.003^{*}$ & -0.003 & -0.005 & -0.005 \\
& $(-1.202)$ & $(-0.427)$ & $(-1.931)$ & $(-0.936)$ & $(-0.311)$ & $(-1.616)$ \\
MARRI & 0.279 & -0.127 & 0.563 & 0.093 & 9.041 & -0.656 \\
& $(0.803)$ & $(-0.159)$ & $(1.197)$ & $(0.104)$ & $(1.506)$ & $(-0.755)$ \\
YEAR & $Y E S$ & $Y E S$ & $Y E S$ & $Y E S$ & $Y E S$ & $Y E S$ \\
Adj. $R^{2}$ & 0.502 & 0.505 & 0.539 & 0.531 & 0.400 & 0.531 \\
$F$ & $21.182^{* * *}$ & $20.535^{* * *}$ & $20.913^{* * *}$ & $19.439^{* * *}$ & $12.398^{* * *}$ & $19.512^{* * *}$ \\
$N$ & 422 & 422 & 359 & 359 & 360 & 360 \\
\hline
\end{tabular}

Note: ${ }^{* * *},{ }^{* *},{ }^{*}$ respectively indicate that the significant level is $1 \%, 5 \%$ and $10 \%$.

Table 8. Anti-corruption intensity, marketization level and food and beverage revenue of five-star hotels

\begin{tabular}{lllllll}
\hline & $(1)$ & $(2)$ & $(3)$ & $(4)$ & $(5)$ & $(6)$ \\
& $F I L$ & $F I L$ & SUSP & SUSP & CAD & $C A D$ \\
\hline$C$ & -0.087 & -0.003 & -0.029 & 0.078 & -0.092 & -0.114 \\
& $(-1.049)$ & $(-0.029)$ & $(-0.324)$ & $(0.733)$ & $(-0.447)$ & $(-0.984)$ \\
ANTICOR & $-0.030^{* * *}$ & $-0.032^{* * *}$ & $-0.034^{* * *}$ & $-0.040^{* * *}$ & -0.004 & $-0.019^{* * *}$ \\
& $(-9.559)$ & $(-6.465)$ & $(-13.900)$ & $(-7.134)$ & $(-0.619)$ & $(-2.754)$ \\
MARKET & $0.346^{* * *}$ & $0.244^{* * *}$ & $0.002^{* *}$ & $0.006^{*}$ & $0.018^{* * *}$ & $0.052^{* * *}$ \\
& $(5.161)$ & $(3.879)$ & $(2.266)$ & $(1.753)$ & $(6.751)$ & $(12.965)$ \\
ANTICOR & & $0.016^{* *}$ & & $0.030^{* *}$ & & $0.099^{* * *}$ \\
$\times$ MARKET & & $(2.270)$ & & $(2.526)$ & & $(2.936)$ \\
FIX & $-0.011^{* * *}$ & $-0.012^{* * *}$ & $-0.013^{* * *}$ & $-0.013^{* * *}$ & $-0.022^{* * *}$ & $-0.015^{* * *}$ \\
& $(-8.613)$ & $(-5.727)$ & $(-9.355)$ & $(-6.091)$ & $(-2.684)$ & $(-3.691)$ \\
CONSUM & $0.168^{* * *}$ & $0.132^{* * *}$ & $0.179^{* * *}$ & $0.128^{* * *}$ & 0.136 & 0.056 \\
& $(6.053)$ & $(4.647)$ & $(6.133)$ & $(4.479)$ & $(0.841)$ & $(0.943)$ \\
URBAN & $0.232^{* * *}$ & $0.238^{* * *}$ & $0.264^{* * *}$ & $0.268^{* * *}$ & $0.386^{* * *}$ & $0.290^{* * *}$ \\
& $(21.567)$ & $(12.682)$ & $(18.423)$ & $(12.576)$ & $(3.537)$ & $(8.250)$ \\
CPI & $-0.151^{* *}$ & $-0.206^{* *}$ & $-0.168^{* *}$ & $-0.204^{* *}$ & $-0.422^{*}$ & -0.081 \\
& $(-2.174)$ & $(-2.336)$ & $(-2.169)$ & $(-2.296)$ & $(-1.890)$ & $(-0.883)$ \\
\hline
\end{tabular}




\begin{tabular}{lllllll}
\hline TOUR & $0.002^{* *}$ & 0.003 & $0.003^{* *}$ & 0.004 & 0.016 & $0.009^{*}$ \\
& $(1.990)$ & $(1.319)$ & $(2.132)$ & $(1.567)$ & $(1.168)$ & $(1.670)$ \\
FOUND & $0.020^{* * *}$ & $0.020^{* * *}$ & $0.018^{* * *}$ & $0.018^{* * *}$ & $0.023^{* * *}$ & $0.014^{* * *}$ \\
& $(11.685)$ & $(10.563)$ & $(9.470)$ & $(7.841)$ & $(2.621)$ & $(3.505)$ \\
VISITOR & $-0.001^{* *}$ & -0.001 & $-0.002^{* * *}$ & $-0.002^{* *}$ & -0.003 & -0.000 \\
& $(-2.255)$ & $(-0.845)$ & $(-4.100)$ & $(-2.146)$ & $(-1.369)$ & $(-0.012)$ \\
SERV & $0.016^{* * *}$ & $0.014^{* * *}$ & $0.017^{* * *}$ & $0.017^{* * *}$ & -0.009 & -0.008 \\
& $(3.425)$ & $(2.764)$ & $(3.803)$ & $(3.045)$ & $(-0.311)$ & $(-0.981)$ \\
GROUP & $0.005^{* * *}$ & $0.006^{* * *}$ & $0.004^{* * *}$ & $0.005^{* *}$ & -0.000 & -0.003 \\
& $(2.760)$ & $(2.754)$ & $(3.103)$ & $(2.350)$ & $(-0.023)$ & $(-0.947)$ \\
MARRI & $-0.492^{* *}$ & -0.739 & $-0.545^{*}$ & -0.713 & 4.498 & $1.899^{* * *}$ \\
& $(-2.297)$ & $(-1.402)$ & $(-1.924)$ & $(-1.248)$ & $(1.486)$ & $(2.646)$ \\
YEAR & $Y E S$ & $Y E S$ & $Y E S$ & $Y E S$ & $Y E S$ & $Y E S$ \\
Adj. $R^{2}$ & 0.620 & 0.617 & 0.693 & 0.673 & 0.458 & 0.407 \\
$F$ & $33.659^{* * *}$ & $31.885^{* * *}$ & $39.527^{* * *}$ & $34.502^{* * *}$ & $15.470^{* * *}$ & $12.200^{* * *}$ \\
$N$ & 422 & 422 & 359 & 359 & 360 & 360 \\
\hline
\end{tabular}

Note: ${ }^{* * *},{ }^{* *},{ }^{*}$ respectively indicate that the significant level is $1 \%, 5 \%$ and $10 \%$.

\subsection{Robustness Tests}

The following sections outline the robustness of the results. On one hand, this study further considers the impacts of the rank of corrupt officials, regional differences in economic development, and the severity of corruption on the development of five-star hotel industry. On the other hand, we use alternative variable measures and alternative research method retesting moderating effects in order to mitigate the potential regression errors.

(1) The Rank of Corrupt Officials and the Development of Five-Star Hotel Industry

The number of cadres at the county level or above in the anti-corruption investigation is used as a measure of anti-corruption. It comes from the China Procuratorate Yearbook and reflects the job title of corrupt officials to a certain extent, but it is relatively general. As for the degree of anti-corruption, the difference in the number of officials punished for corruption at different levels can reflect the difference in the intensity of anti-corruption. The more senior officials are punished, to some extent, the stronger the anti-corruption efforts are. From the perspective of the influence of different levels of officials on the development of five-star hotel industry, the higher the level of officials, the greater the administrative power, and the higher the potential consumption capacity in five-star hotels. When senior officials are punished for corruption, they have a greater deterrent force and have a greater influence on the development of five-star hotel industry.

The information disclosed in the China Procurator Yearbook basically covers the number of corrupt cadres at or above the county level in each district, and partially covers the number of corrupt cadres at the bureau level, but does not disclose the number of corrupt cadres below the county level, at the provincial level, or at the national level. In order to further explore the 
impact of the level of corrupt officials on the development of the five-star hotel industry, this paper further analyzes the regression model using the number of bureau-level cadres $(B L N)$ in the anti-corruption investigation. The number of bureau-level cadres $(B L N)$ in the anti-corruption investigation department is negatively and significantly associated with the total revenue and room revenue of five-star hotels at $1 \%$ level. The coefficients on the interaction terms between $B L N$ and marketization (MARKET) is significantly positive at $5 \%$ level. The regression results are basically consistent with the existing research conclusions, but the level of significance is significantly improved. The development effect of the "corrupt economy" of five-star hotels will be different due to the level of duties of corrupt officials. However, the difficulty of data collection can only be explored at the level of bureaucrat-level corrupt officials.

(2) Regional Differences in Economic Development, the Severity of Corruption and the Growth of the Five-star Hotel Industry

This paper explores the relationship between anti-corruption and the development of five-star hotel industry by using the provincial panel data of 31 regions in China. Considering the differences in the degree of corruption among different regions, this paper screened 31 regions based on economic development and the severity of corruption. In terms of the degree of economic development, due to five-star hotels in the western region are relatively backward, we re-selected the economically developed areas as samples to regress after excluding 12 provinces in the western region (Sichuan, Chongqing, Guizhou, Yunnan, Shaanxi, Gansu, Qinghai, Ningxia, Xinjiang, Guangxi, Inner Mongolia, Tibet). In terms of the severity of corruption, this paper divides the total sample into severely corrupt areas and lightly corrupt areas according to the median number of corruption filings $(F I L)$ and the number of people involved in corruption $(S U S P)$ in the 31 regions during the period 2000-2014. The relationship between anti-corruption and the development of the five-star hotel industry is re-explored by using the samples from the areas with serious corruption from 2000 to 2014. The regression results obtained from the above-mentioned samples are basically consistent with the existing conclusions.

(3) Alternative Control Variables

The level of service facilities, industry economic situation, and tourism consumption income are also important factors affecting the development of the five-star hotel industry. The data of service facilities and the economic situation of the industry are lacking in some sample interval. Tourism consumption income includes the consumption income of travel agencies and star-rated hotels, covering the income of five-star hotels in this paper. Considering the above data loss and variable's relationship, this paper does not include service facility level, industry economic situation, and tourism consumption income as control variables in the basic model, but as a robust check. We use the size and quantity data of five-star hotel rooms in each district of China Travel Yearbook to build a service facility level variable (SERVICE). Trend of Industry (TIND) is characterized by the proportion of regional accommodation and catering industry production to the regional GDP. Tourism Income (TINC) is the natural logarithm of the operating income of tourism companies in the copy of China Tourism Statistics Yearbook. The regression results are basically consistent with the previous conclusions. 
(4) Retest of Moderating Effects

This paper uses the interaction term between anti-corruption and marketization to verify the moderating effect of marketization level in the relationship between anti-corruption and the growth of five-star hotel industry. To ensure the reliability of the regression results, we separated the sample into two groups according to the median of the marketization process variables, and the moderating effect of the market-oriented process is re-examined. The regression results show that the negative association between anti-corruption and the growth of the five-star hotel industry is weakened in regions with high marketization levels, but this moderating effect of the marketization process is more reflected in the five-star hotel catering revenue. When the dependent variable is the income of a five-star hotel room, the moderating effect of the marketization process is significantly reduced. The regression results are basically consistent with the existing conclusions.

\section{Conclusion}

Using the panel data of five-star hotel industry between 2000 and 2014, from the perspective of corruption and anti-corruption, this paper analyzes the growth mechanism of the five-star hotel industry, discusses the applicability of the "corruption economy" model in China's five-star hotels and the applicability of the "corruption economy" model in China, explores the sound development path of China's five-star hotels in the anti-corruption situation from the dimension of marketization process. The conclusions of this paper are as follows:

(1) The degree of national corruption has a positive effect on the growth of the five-star hotel industry. That is, the more serious the degree of corruption in China as shown in the World Bank's Global Government Governance Indicators Database, the better the revenue growth of Chinese five-star hotels. Under China's imperfect socialist market economic system, the government's intervention in the economy is greater. Simultaneously, government officials' corruption spending is directly linked to five-star hotels. When the degree of corruption is higher, the government officials use privilege to create rents, and five-star hotels use rent-seeking to establish good political and business relations to obtain scarce resources, which promotes the development of five-star hotels to a certain extent. The conclusions of this paper verify the theory of political rent-making and rent-seeking theory in the five-star hotel industry in China.

(2) The stronger the anti-corruption policy and enforcement in China, the greater the negative impact on the business scope of five-star hotels in China. Both guest rooms and catering business are affected by anti-corruption in varying degrees and show a shrinking trend. Anti-corruption punishing officials' corrupt behavior enhances the transparency of the government's executive power, promotes the fairness of the government's resource allocation and approval, and cuts off the traditional path of five-star hotels trying to achieve rapid development through political connections. To a certain extent, five-star hotel industry growth has caused a negative impact.

(3) To some extent, the process of marketization has restrained the decreasing effect of anti-corruption on the growth of five-star hotel industry. The market mechanism is more perfect, the resource allocation efficiency is higher, the market competition mechanism is fairer, and the intensity of government intervention in the economy is more reasonable, which 
is conducive to guiding five-star hotels to participate in the competition through the formal market channels. It can reduce the rent-seeking and dependence of five-star hotels on government departments and realize the decreasing trend of income of five-star hotels under the situation of anti-corruption and high pressure.

Different from previous studies, this paper does not explore the relationship between corruption, anti-corruption and the total amount of economic growth, but chooses a special representative five-star hotel industry to explore the impact of corruption and anti-corruption on the development of five-star hotel industry. The research results of this paper indicate that corruption is beneficial to the growth of the total revenue of five-star hotels, and anti-corruption has caused the decline of the business volume of five-star hotels to a certain extent. On the surface, the conclusion of this paper seems to provide empirical support for the positive affections of corruption. However, in fact, this paper attempts to explore the development mode of improving the "corrupt economy" of five-star hotel under the view of negative affections of corruption, and explores the realistic path of sustainable and healthy development of five-star hotel industry in China. We argue that corruption is bad for sustainable economic growth. The fundamental reason that corruption promotes the growth of five-star hotel industry lies in the fact that five-star hotel is the demand side of corruption and an important consumption place for corrupt behavior of government officials. The positive influence of official corruption on the five-star hotel industry is a deformed "corrupt economy" development model, which can only bring about the false prosperity of the five-star hotel industry. The economic consequences of official corruption are dual in nature. For bribe-bribing enterprises, it is convenient to take advantage of bribe-taking officials to enter the rapid development channel; for non-bribe-paying enterprises, it is naturally the victim of official corruption.

The research results of this paper verify that the inhibition effect of anti-corruption on the development of five-star hotel industry showing a reverse trend in the areas with high degree of marketization. This paper agrees with the important role of the perfection of market mechanism, but it is different from the argument of rent seeking opinion. Rent-seeking theory holds that corruption originates from government intervention in the economy. The effective way to solve corruption is to reduce public power, reduce the scale of government, and let the market dominate the economy. This paper advocates the effect of marketization in anti-corruption, but does not agree with the theory of "small government, big society". We think that in the period of economic and social transformation in China, it is necessary for the government to intervene in the economy moderately, and the vigorous promotion of anti-corruption policy under the premise of the existence of public power will help to curb the corrupt behavior of government officials to establish a better government.

From the macro angle of view, only by deepening the reform of market-oriented mechanism, maintaining the government's reasonable intervention in the economy and forming a well-ordered market competition system, can five-star hotels achieve sustainable and effective development. At the micro level, five-star hotels should adjust their development strategy in time, pay attention to the diversified needs of customers, pay attention to service model innovation, actively explore new revenue growth points, and abandon the traditional five-star hotel development model, which depends on government consumption. So that 
China's five-star hotel really towards prosperity and development. Further, the formation of a perfect market mechanism in the five-star hotel industry lets the market play a decisive role in the allocation of resources, which is beneficial to the implement of China's anti-corruption policy. Government officials are renters and enterprises are seeking rents. Corruption occurs only when both exist at the same time. The anti-corruption policy is an effective way to solve this problem. From the perspective of norms of rent-seeking parties, when the five-star hotel has realized a sound operation under the market mechanism, the demand for government officials has been reduced, and the rent-seeking willingness has declined. It also has a certain degree of promoting effect for the government of different administrative divisions in China to control corruption.

\section{Acknowledgments}

The authors thank the financial support of the National Natural Science Fund of China (71402004, 71072096, 15YJC790099).

\section{References}

Aidt T. (2009). Corruption, Institutions and Economic Development. Oxford Review of Economic Policy, 25, 271-291. https://doi.org/10.1093/oxrep/grp012

Alm, J., Martinez-Vazquez, J., \& McClellan, C. C. (2016). Firm, Tax Evasion. Journal of Economic Behavior \& Organization, 124, 146-163. https://doi.org/10.1016/j.jebo.2015. 10.006

Bentzen, J. S. (2012). How Bad is Corruption? Cross-country Evidence of the Impact of Corruption on Economic Prosperity. Review of Development Economics, 16(1), 167-184. https://doi.org/10.1111/j.1467-9361.2011.00653.x

Cheung, Y. L., Rau, P. R., \& Stouraitis, A. How Much Do Firms Pay as Bribes and What Benefits Do They Get? Evidence from Corruption Cases Worldwide. Working Paper, National Bureau of Economic Research.

D’ agostino, G., Dunne, J. P., \& Pieroni, L. (2016). Government Spending, Corruption and Economic Growth. World Development, 84(C), 190-205. https://doi.org/10.1016/j.worlddev. 2016.03.011

Donadelli, M., Fasan, M., \& Magnanelli, B. S. (2014). The Agency Problem, Financial Performance and Corruption: Country, Industry and Firm Level Perspectives. European Management Review, 11(3-4), 259-272. https://doi.org/10.1111/emre.12038

Ghalwash, T. (2014). Corruption and Economic Growth: Evidence from Egypt. Modern Economy, 5(10), 1001-1009. https://doi.org/10.4236/me.2014.510092

Hessami, Z. (2014). Political Corruption, Public Procurement, and Budget Composition: Theory and Evidence from OECD Countries. European Journal of Political Economy, 34(6), 372-389. https://doi.org/10.1016/j.ejpoleco.2014.02.005 


\section{Macrothink}

Issues in Economics and Business

ISSN 2377-2301

2019, Vol. 5, No. 2

Iqbal, N., \& Daly, V. (2014). Rent Seeking Opportunities and Economic Growth in Transitional Economies. Economic Modelling, 37(574), 16-22. https://doi.org/10.1016/ j.econmod.2013.10.025

Michael, T. R., \& Heidi, B. (2004). The Comparative Politics of Corruption: Accounting for the East Asian Paradox in Empirical Studies of Corruption, Growth and Investment. World Development, 32(6), 999-1017. https://doi.org/10.1016/j.worlddev.2003.12.002

Mushfiq, S. (2011). Economic growth with endogenous corruption: an empirical study. Public Choice, 146(1), 23-41. https://doi.org/10.1007/s11127-009-9581-1

Pak, H. M. (2001). Corruption and Economic Growth. Journal of Comparative Economics, 29(1), 66-79. https://doi.org/10.1006/jcec.2000.1703

Pan, X. F., \& Tian, G. G. (2017). Political Connections and Corporate Investments: Evidence from the Recent Anti-Corruption Campaign in China. Journal of Banking and Finance. https://doi.org/10.1016/j.jbankfin.2017.03.005

Paunov, C. (2016). Corruption's Asymmetric Impacts on Firm Innovation. Journal of Development Economics, 118, 216-231. https://doi.org/10.1016/j.jdeveco.2015.07.006

Pulok, M. H., \& Ahmed, M. U. (2017). Does Corruption Matter for Economic Development? Long Run Evidence from Bangladesh. International Journal of Social Economics, 44(3), 350-361. https://doi.org/10.1108/IJSE-05-2015-0132

Raul, A. B. (2001). Endogenous Corruption, Inequality and Growth: Econometric Evidence. Working Paper. Raul A Barreto. Endogenous Corruption, Inequality and Growth: Econometric Evidence. https://media.adelaide.edu.au/economics/papers/doc/wp2001-02

Wang, L. Y. (2016). The Impacts of Anti-Corruption on Economic Growth in China. Modern Economy, 7(2), 109-117. https://doi.org/10.4236/me.2016.72013

\section{Copyright Disclaimer}

Copyright for this article is retained by the author(s), with first publication rights granted to the journal. This is an open-access article distributed under the terms and conditions of the Creative Commons Attribution license (http://creativecommons.org/licenses/by/3.0/). 